\title{
Administrative Growth At The "University": A Case Study
}

Leon B. Hoshower, (E-mail:hoshower@oak.cats.ohiou.edu), Ohio University David Kirch, Ohio University

\begin{abstract}
During the past two decades, the cost of higher education has increased at a higher rate than inflation. Although this increase is small each year, the cumulative effect is great. These increased costs are funded mainly through increased tuition and increased government support, either through subsidies to state funded universities or through government supported student loans, grants, work-study programs, and tax credits. These subsidies are straining governmental budgets. Many students are graduating with large debt burdens. There is a rising fear among the working class that providing a college education for their children will be beyond their financial means.
\end{abstract}

Thus, it is generally understood that the cost of a college education is rising faster than inflation and that these rising costs are creating a financial burden for both governments and individuals. What is not generally understood is the source of these rising costs. This study examined the financial records of a state supported, mid-western university with enrollment between 15,000 and 20,000 students, hereafter referred to as the University, over an eighteen-year period. The study found that the rising cost of the University's administration was the major source of the university's cost increases. This paper documents this finding and offers five possible explanations for these rising administrative costs. The paper neither condemns nor justifies the rises in costs and it offers no suggestions for effectively decreasing administrative costs. Diagnosis of the problem is the current topic of discussion, while possible solutions remain to be devised at a later date.

\section{INTRODUCTION}

t's as traditional as Spring Break, the University President's announcement and justification of the
annual tuition increase. Usually, the ritual starts with one of the braver universities announcing next
year's tuition increase with an accompanying explanation in the local newspaper. "State Cuts Force College Costs Up" (Toledo Blade, February 10, 2002) was typical of these announcements. In Ohio, this year's announced tuition increases were usually high and evoked a particularly tumultuous public uproar. The article in the Toledo Blade (February 16, 2002), "Tuition Hikes Protested in Postcard Push" documented the public's response. Next, the politicians waded in crying for "Colleges to Trim Tuition Hikes" (Cleveland Plain Dealer, February 27, 2002). Finally, everyone settled down and seemingly accepted the apparently inevitable tuition increases, as modified downward slightly by the political pressure. The Columbus Dispatch's (March 5, 2002) article reported the end of this year's tuition controversy, "Settled For Now, Taft, Universities Compromise Over Tuition".

Inherent in this whole process, it seems, is the public's belief that the tuition increases will be used to better educate the next generation. This paper examines the budgets of one medium sized state university in the Midwestern United States to determine where the money goes. 


\section{The Current Study}

During the last two decades, the cost of higher education has increased at a higher rate than inflation. ${ }^{1} \mathrm{Up}$ to the past couple of years, these increases have tended to relatively small each year, but the cumulative effect has continued to surpass inflation by a wide margin. Recently the amount of the increases has been accelerating. These increased costs are funded mainly through a combination of increased tuition and increased government support. This support can be either in the form of subsidies to state funded universities or through government supported student loans, grants, work-study programs, and tax credits. These subsidies strain governmental budgets at all levels. Even with the subsidies, most students graduate with large debt burdens. There is a rising fear among the working class that providing a college education for their children will be beyond their financial means.

What is not generally understood is the source of the rising costs, which are fueling these calls for increased tuition and subsidies. This study examined the financial records of a state supported, mid-western university with enrollment between 15,000 and 20,000 students, hereafter referred to as the University, over a nineteen-year period. The study found that the rising cost of the University's administration was the major source of the university's cost increases. This paper documents this finding and offers five possible explanations for these rising administrative costs. The paper neither condemns nor justifies the rises in costs and it offers no suggestions for effectively decreasing administrative costs. Diagnosis of the problem is the current topic of discussion, while possible solutions remain to be devised at a later date.

\section{FINDINGS AT THE UNIVERSITY}

Table 1, shown below, summarizes the findings of our study. The year 1982 was the base year for the study because it is the first earliest year for which electronic records of budget data is maintained. There were some problems in classifying some employees as either faculty or administration. For example, is a department chair, whose teaching load is one-half of that of a normal faculty, an administrator or a faculty? To avoid the possibility of the researchers' classifications biasing the results, we used the University's classification of employees as administrative or faculty in all the data analysis shown below. All dollar amounts are adjusted to year 2000 dollars.

\section{Table 1: Summary Statistics for the University}

Full-Time Faculty

Visiting and part-time

Total Number of Faculty

Total Number of Administrators

Average Salary for full time Faculty

Average Salary for Administrators

Total Salaries for Faculty

Total Salaries for Administration

Total Students

\begin{tabular}{lll}
1982 & 2000 & $\%$ Change \\
\hline 652 & 878 & $35 \%$ \\
160 & 257 & $61 \%$ \\
812 & 1,135 & $40 \%$ \\
535 & 1,457 & $124 \%$ \\
$\$ 53,421$ & $\$ 60,296$ & $13 \%$ \\
$\$ 41,869$ & $\$ 47,666$ & $14 \%$ \\
$\$ 36,297,228$ & $\$ 58,107,451$ & $60 \%$ \\
$\$ 22,106,993$ & $\$ 56,338,496$ & $154 \%$ \\
14,576 & 19,327 & $33 \%$
\end{tabular}

Table 1, above, shows that the number of full time faculty employed at the University grew from 652 in 1982 to 878 in 2000 , a 35 percent increase. This compares to a 61 percent increase in part time and visiting faculty, whose numbers grew from 160 in 1982 to 257 in 2000 . The increase in total faculty during the period was 40 percent. Meanwhile, the number of administrators grew from 528 in 1982 to 1,183 in 2000, a 124 percent increase. During the period student enrollment at the University increased by 33 percent.

\footnotetext{
${ }^{1}$ From 1996 to 2000, for instance, these costs rose at a rate of about 5\% per year. (University Fact Book, 2001, p53)
} 
Table 1 also shows the average salary for full time faculty members at the University in 1982 was $\$ 53,421$ (adjusted for inflation to 2000 dollars). In the 2000 school year, the average salary was $\$ 60,675$. In 1982 , the average salary for administrators was $\$ 41,869$ (adjusted to 2000 dollars) and in 2000, the average salary was $\$ 47,666$. Thus, the average full time faculty salary increased 13 percent in real purchasing power, while the average administrative salary increased 14 percent in real purchasing power over the 18 -year period.

While average salaries of faculty and administrators increased at relatively the same rate, the University's total expenditures for faculty and administrative salaries did not. Total faculty salary expenditures increased by $60 \%$, adjusted for inflation, during the period, while total administrative salaries increased by $154 \%$, adjusted for inflation. One noteworthy finding is that there are now more administrators at the University than faculty. (We like to fantasize that there is one administrator assigned to each faculty member, just to look after our well being, like a guardian angel looking over our shoulder.) Similarly, the total salary of administrators is almost as much as the total salaries of all classes of faculty. Should the trend continue, the total salaries of administrators would eclipse the total salary of the faculty in a few years. This data shows that an increasing proportion of budgetary expenditures are used for managing the organization, while the proportion of expenditures for instructing students decreases.

As stated above, we found that average salaries of administrators and faculty members increased at relatively the same rate. Upon further investigation we found that within administrative salaries, the salaries of top administrative officials rose at a much higher percentage than the salaries of lower salaried administrators. The average, inflation adjusted, administrative salary increase during the period was 14 percent. This compares to a salary increase of 91 percent for the president, 61 percent for the provost, 125 percent for the vice-presidents, and the 71 percent for the assistant vice-presidents.

In addition to examining the salary increases of top university officials, we also examined the increase in the number of top ranking officials. The number of administrators whose title includes the word president, vicepresident, or provost increased 131 percent, which is about the same proportional increase as the rest of the administration during the period.

The phenomenon of rising administration costs is not isolated to the University. It is a national trend in both public and private universities. Other studies have revealed that this is a pervasive trend that has permeated higher education as a whole. The estimated increase of administrative costs adjusted for inflation between 1975 and 1985 was sixty percent nationwide (Stanley and Adams). Studies of universities in the states of Massachusetts, Iowa, Minnesota, Michigan, and California have uncovered the same facts that administration costs have grown faster than faculty costs.

The rising cost of administrative salaries has not only been funded by an increasing toll on the taxpayers, parents and students of the University. There has also been a trend toward hiring more part-time and adjunct faculty. Part time and adjunct faculty typically have lower academic credentials and are paid much less than the more academically qualified full time faculty. Many part-time faculty have full time jobs elsewhere and teach on short-term contracts. Presumably then, they have less time to commit to classroom instruction and have less commitment to the long-run well being of the University. In 1982, there were 149 part-time faculty who received an average, inflation adjusted, salary of $\$ 7,369$. By 2000 there were 234 faculty in this classification with an average salary of $\$ 18,379$. The increase in the salary is misleading as faculty in this classification are often paid by the number of classes they teach. We believe that this increase in average salary is due to an increase in the average number of classes taught per part-time instructor. So, the number of part-time instructors increased by 57 percent during the period and we assume that these faculty are teaching more classes per instructor. This data demonstrates the University's increased reliance on adjunct type faculty who teach for a much cheaper per student basis. Given the University's propensity to reallocate its expenditures to administration, and the disparity in cost on a per student basis, it is easy to understand the administration's succumbing to the temptation of using lower paid and presumably lower skilled part-time/adjunct faculty to staff its classes. 


\section{REASONS FOR EXPANDING ADMINISTRATIVE COSTS}

This section presents five explanations for the seemingly inordinate growth of administration. These five explanations are: normative processes of organizations, the Harvard Theory, increasing state and federal regulations, the theory of growing organizations, and increasing emphasis on research.

\section{NORMATIVE PROCESSES}

Institutional theory provides the mechanism of "normative process" to explain the growth of administrative costs. Normative process states that, over time, management becomes more professionalized and more involved in professional associations. The theory contends that through professional organizations, administrators share philosophies and ideologies and ultimately assimilate a common worldview. Consequently, these decision makers adopt the organizational structures that are discussed at professional meetings (Leslie and Rhoades). So whenever a high status university creates a "Director of XYZ" position, other universities soon create their own Director of XYZ position. Through the normative process administrations attempt to be accepted by the professional community by subscribing to the currently accepted view of university structures. Thus, over time, universities tend to develop similar structure and practices.

\section{THE HARVARD THEORY}

The Harvard Theory is similar to the normative process. Its states that when faced with environmental uncertainty, managers will increasingly adopt the administrative structures developed by successful organizations (Leslie and Rhoades). For the academic managers, the organization more commonly mimicked is Harvard. Simply stated, the Harvard Theory contends that if Harvard is doing something then it must be right. Thus, if Harvard has increasing administration costs and increasing tuition, these are signs of a healthy and successful university. Consequently, according to this theory, our university's administrators may view our increasing administrative costs and tuitions not as a problem, but rather as an evidence of our success.

\section{STATE AND FEDERAL REGULATION}

According to Leslie and Rhoades in Rising Administrative Costs, "increased state and federal regulatory pressure on higher education is associated with the growth of administrative staff and expenditure." Two government regulations, which placed major compliance burdens on university administration during the past two decades, are the Americans with Disabilities Act (1990) and Title IX as it applies to inter-collegiate athletics.

The University created a new administrative branch, the Disability Services Office, to comply with the ADA (Skeeles). From December 1993 to July 1994, the University conducted an interdepartmental study that showed that the University was far from Title IX compliance. Since that study, the University added women's golf in the fall of 1996, women's soccer in fall of 1997, and women's lacrosse in winter of 1998 (Ayres) (Koch). The additional three varsity sports for women increased the number of athletic administrators at the University.

The above two government regulations discussed above are but two examples of many rules and regulations imposed by the state and federal government. Compliance with each of these rules requires more administration. So one reason why the University has more administrators now than 18 years ago is that the regulatory environment of higher education requires more record keeping and statutory compliance.

\section{GROWING ORGANIZATIONS}

The larger an institution becomes, the greater the share of its expenditures that will be devoted to administration (Leslie and Rhoades). Since student enrollment grew by 38 percent during the period from 1982 to 2000, according to this theory we would expect administrative costs to increase by more than 38 percent over this period. Apparently, the administration of most organizations experiences decreasing economies of scale. 
As stated earlier, the number of administrators increased by 124 percent from 1982 to 2000 and total administrative salaries, adjusted for inflation, increased by 154 percent. Although the previous theories presented tell us to expect an increase, we were surprised by the magnitude of this increase. This increase in the number of administrators coincides with the increasing complexity of the University's organizational structure as reflected by the increase in the number of associate and assistant provosts, deans, and directors.

\section{Increasing Emphasis on Research}

Research universities need to be more complex organizationally than the traditional teaching institutions. Applying for research grants, administering grants, and conducting research are expensive and complex tasks and thus require more administrative overhead. This problem is compounded by the fact that as the amount of research conducted at a university increases, the amount of administrative functions performed by faculty decreases. Universities, which emphasize research, relieve their faculty of administrative tasks so that the faculty can devote an increased proportion of its time to research. Similarly, to be competitive in attracting researchers, universities must lighten the administrative duties of their research faculty. Thus, research increases the need for administrators in two ways. First, it creates more administrative work. Second, it shifts administrative duties from faculty to administrations.

There has been an ever-increasing emphasis on research at the University, as there have been at most universities, during the past two decades. Thus, the increase in research explains some of the increase in administrative costs.

\section{CONCLUSION}

This paper reveals that total administrative salaries during the past two decades have increased much faster than either total faculty salaries or student enrollment. This disproportional increase in total administrative salaries is due to a disproportional increase in the number of administrators, rather than a difference in average salary increases. Upon further investigation we found that within administrative salaries, the salaries of top administrative officials, like the president, the provost, the vice-presidents, and the assistant vice-presidents, rose at a much higher percentage than the salaries of lower level administrators or of faculty.

This difference in the increase in total salaries for faculty and administration appears to mirror the national trend. While several theories presented in the paper can explain the disproportional increase in administrative salaries, they offer no solution to this phenomenon. We invite the creation of additional research to discover methods of controlling university administration costs and re-centering the focus of higher education institutions on students and education. The final stage of institutional research should be to uncover solutions to reverse this national trend and thus stop the constantly rising cost of higher education.

We wish to acknowledge Cassie Cole, Dan Gordish, Leslie Hampel, and Joy White (all graduates of Ohio University) for their contributions to this project.

\section{REFERENCES}

1. Ayres, Brian. (1997, September 26). "Delay in Third Sport Decision May be Over at Ohio University". "The Post." [On-line]. Available: http://web.lexis-nexis.com.

2. Koch, Joel. (1998, February 3). "Ohio University to Add Women's Lacrosse in Title IX Move." The Post. [On-line]. Available: http://web.lexis-nexis .com.

3. $\quad$ Larson, Erik. (1997, March 17). "Why Colleges Cost Too Much.”Time. 149(11), 46-55.

4. Leslie, Larry L. and Rhoades, Gary. (1995, March/April). "Rising Administrative Costs." Journal of HigherEducation. 66(2), 187-212.

5. $\quad$ Ohlemacher, Stehen. "Colleges to Trim Tuition Hikes." The Plain Dealer. February 27, 2002.

6. Ohio University. Office of Institutional Research Fact Book, December 2001. Ohio University. (Published Annually). 
7. Overview of Title IX. (1995). [On-line]. Available: http://bailiwick.lib.uiowa.edu.

8. "Settled For Now" Columbus Dispatch, March 5, 2002, 10A.

9. Skeeles, Heather. (2000, March 6). "Ohio University Campus Challenging for Students, Faculty With Disabilities.” The Post. [On-line]. Available: http://web.lexisnexis.com.

10. Smith, Ryan. "State Cuts Force College Costs Up." The Toledo Blade, February 10, 2002.

11. Stanley, Elizabeth C. and Adams, Jean W. (1994). "Analyzing Administrative Costs and Structures". Research in Higher Education. 35(1) 125-140.

12. The Americans with Disabilities Act. (1990). [On-line]. Available: http://www.oberlin.edu.

13. Title IX, Education Amendments of 1972. (1972). [On-line]. Available: http://www .dol.gov.

14. "Tuition Hikes Protested in Postcard Push." Toledo Blade, February 16, 2002.

Notes 